\title{
Bagaimana Konstruksi Gender dalam Permainan Outdoor di PAUD?
}

\author{
Maya Lestari \\ School of Postgraduate Studies \\ Universitas Pendidikan Indonesia \\ Email : mayalestari@upi.edu
}

\begin{abstract}
Abstrak :Bermain menjadi sebuah bagian yang tidak terpisahkan dari dunia anak. Artikel ini berfokus pada permainan outdoor sebagai permainan fisik pertama. Yang saya maksud dengan permainan outdoor di artikel ini termasuk bermain sepak bola, lompat tali, dan permainan outdoor lainnya Ada anggapan yang diyakini secara luas bahwa gender merupakan salah satu faktor analitis dalam permainan anak. Mitosnya adalah anak laki-laki memiliki minat bermain outdoor yang lebih tinggi daripada anak perempuan. Termasuk didalamnya pada penguasaan tempat bermain. Dengan demikian, menganalisis diskursus permainan outdoordalam pendidikan anak usia dini dari perspektif gender akan berkontribusi pada pemahaman pengembangan permainan dalam pendidikan anak usia dini. Melalui penelitian studi etnografi di sebuah taman kanak-kanak di Palembang Indonesia, artikel ini menemukan adanyarelasi kuasa dalam permainan outdoor anak di TK dan menelitibagaimana guru, orang tua dan orang dewasa lainnya mengatasi kesenjangan gender dalam permainan outdoor.
\end{abstract}

Kata Kunci :Anak, Isu Gender, Outdoor, Permainan

\begin{abstract}
Playing is an inseparable part of the child's world. This article focuses on outdoor play as the first physical game. What I mean by outdoor play in this article includes playing football, jumping rope, and other outdoor games. There is a widely held assumption that gender is an analytical factor in children's play. The myth is that boys have a higher interest in outdoor play than girls. Includes mastering the place to play. Thus, analyzing the discourse of outdoor play in early childhood education from a gender perspective will contribute to understanding game development in early childhood education. Through a case study research at a kindergarten in Palembang Indonesia, this article finds power relations in children's outdoor games in kindergarten and examines how teachers, parents and other adults address the gender gap in outdoor games.
\end{abstract}

Keywords :Children, Gender issues, Outdoor, Play

\section{PENDAHULUAN}

Bahasan tentang gender dan hubungannya dengan pilihan permainan di konteks anak usia dini masih menjadi hal yang diperdebatkan. Meskipun diyakini secara luas pengkotak-kotakan perbedaan gender dalam pilihan permainan ini sudah terjadi sejak lama dan masih terjadi hingga saat ini. Tidak terlepas di dunia pendidikan anak usia dini di Indonesia.
Perbedaan gender dalam permainan ini tidak hanya terjadi ketika anak sedang bermain di dalam ruangan baik itu ketika di sekolah maupun dirumah. Seperti misalnya yang di luaskan di masyarakat, bahwa anak perempuan idealnya bermain dengan permainan perempuan seperti boneka dan segala hal yang diidentikkan dengan kewanita-wanitaan, dan anak laki-laki idealnya bermain dengan permainan laki-laki 
seperti mobil-mobilan dan segala hal yang diidentikkan dengan kelaki-lakian. Perbedaan gender dalam pilihan permainan ini juga terjadi pada permainan luar ruangan (outdoor). Perbedaan-perbedaan gender dalam pilihan permainan ini didukung oleh mitos-mitos yang berkembang luas di masyarakat. Mitosnya, anak laki-laki memiliki kecenderungan minat yang lebih besar untuk melakukan aktivitas fisik pada kegiatan luar ruangan (outdoor) dibandingkan anak perempuan.

Studi tentang gender dan permainan di setting PAUD juga dilakukan oleh (Adriany, 2019b, 2019a; Dinella \& Weisgram, 2018; Kollmayer, Schober, \& Spiel, 2018) yang dalam penelitiannya melihat bagaimana gender dan adanya relasi kuasa dalam pilihan permainan anak.

Permainan outdoor di setting PAUD cenderung bersifat hitam dan putih. Sekolah seringkali menjadi tempat yang mengajarkan nilai-nilai baik secara implisit maupun eksplisit kepada anak tentang apa yang boleh dan tidak boleh, termasuk dalam permainan apa yang ideal dimainkan oleh anak perempuan dan apa yang ideal dimainkan oleh anak laki-laki. Sehingga ini menimbulkan kerugian pada salah satu pihak yang akses pada ruang bermainnya terbatasi karena sekolah melegalkan pengkotakkotakan pilihan permainan dan mengekalkan bias gender sejak dini.
Dengan memberikan akses yang seluasluasnya pada anak perempuan dan anak lakilaki dalam kegiatan bermain akan mempengaruhi cara pandang anak terhadap lingkungan sosialnya, juga kreativitas anak ketika bermain akan lebih berkembang melalui dekonstruksi mitos gender dalam permainan outdoor di PAUD.

\section{KAJIAN TEORITIK}

Gender berbeda dengan jenis kelamin. Jenis kelamin (sex) adalah sesuatu bawaan yang ditentukan secara biologis yang melekat pada jenis kelamin tertentu dan berlaku untuk semua makhluk yang bereproduksi. Sedangkan gender adalah suatu istilah yang digunakan untuk manusia dan mengandung arti yang berkaitan dengan semua atribut kompleks terhadap laki-laki dan perempuan yang berasal dari budaya (Fakih, 2013)

Diyakini secara luas, konstruksi gender umumnya berasal dari kondisi, pengalaman, dan kemungkinan-kemungkinan tertentu yang berbeda pada setiap budaya, yang kemudian dipasangkan dengan kewanitaan dan kelaki-lakian, dan ini merupakan kategori sosial utama yang digunakan oleh kebanyakan masyarakat sebagai dasar untuk sosialisasi dan untuk penentuan status sosial termasuk dalam permainan.

Ketika anak belajar tentang gender, ia juga belajar tentang labeling, termasuk dalam pilihan permainan. Pada umunya, 
masyarakat seringkali menghubungkannya dalam permainan yang membeda-bedakan antara permainan anak laki-laki dan anak perempuan, meskipun secara struktur, tingkatan, dan pasangan atau teman bermainnya ini dinegosiasikan dari budaya. Padahal, Sejak usia 3 tahun, ketika kemampuan kognitif anak mampu untuk mengidentifikasi gender dalam diri mereka dan orang disekitarnya, maka perbedaan gender dalam permainan pun mulai meningkat secara kompleks dan alami seiring anak melakukan perubahanperubahan dalam permainannya (Lynch, 2015)

Yang dibangun masyarakat, bahwa melalui labeling ini dapat menjadi langkah awal dalam memahami gender yang mengindikasikan bahwa seorang anak mulai berpikir tentang dunia dan berperilaku berbeda-beda. Dimana anak-anak dapat melabeli gender orang lain sejak dini. Pelabelan gender juga berhubungan dengan pilihan teman bermain dan pola bermain. Kehadiran orang dewasa lainnya disekitar anak, praktik pengasuhan anak dan penyediaan mainan yang diidentikkan berdasarkan jenis kelamin juga dapat memengaruhi identitas gender dan preferensi permainan anak-anak, dan bagaimana pengaruh sosialisasi dapat memediasi hubungan antara kognisi dan perilaku gender anak.

Segregasi atau pemisahan gender, yang akan kita bahas berikutnya, adalah aspek penting lain dari budaya gender ini. Segregasi gender ini dimulai sejak dini sejak perayaan menyambut kelahiran dan bertahan sepanjang rentang kehidupan manusia. Di sebagian besar budaya, praktik ini dimulai sejak usia 3 tahun. Ada bukti perbedaan dalam preferensi permainan, dengan permainan anak laki-laki sering melibatkan permainan yang lebih kasar dan berantakan dan permainan anak perempuan melibatkan lebih banyak melibatkan kolaborasi. Beberapa temuan mengungkapkan bahwa bermain kelompok dengan jenis kelamin yang sama lebih kooperatif daripada kelompok campuran jenis kelamin. Anak perempuan yang berusaha berpartisipasi dalam kegiatan lintas gender, dianggap paling buruk dan diabaikan. Anak laki-laki yang berusaha berpartisipasi dalam kegiatan lintas gender sering menerima umpan balik negatif dari anak laki-laki dan perempuan.

Pengekalan Gender stereotype ini umumnya terjadi karena banyak anak yang tinggal di lingkungan dan bersekolah di sekolah yang ras, budaya, dan ekonomi dan perspektif gender yang terpisah. Anak lakilaki biasanya memberlakukan lebih banyak superhero dan menggunakan lebih banyak agresi fisik dan verbal daripada anak perempuan. 
Gender stereotype ini menjadi isu gender yang seringkali diabaikan dalam Pendidikan Anak Usia Dini (MacNaughton, 2000). Guru dan orang tua seringkali beranggapan bahwa isu gender tidaklah penting untuk anak usia dini. Anak sering kali dianggap sebagai individu yang belum bisa memahami arti gender dan karenanya tidak perlu diperkenalkan dengan isu ini (Adriany, 2019a). Dalam konteks masyarakat Indonesia, isu gender seringkali dianggap sebagai sebuah isu yang cukup kontroversial untuk diajarkan pada anak usia dini. MacNaughton (2000) juga mengemukakan pengabaian isu gender di setting PAUD sebetulnya merupakan sebuah tindakan yang sangat merugikan bagi anak. Beliau mengungkapkan bahwa ketika isu gender tidak diperkenalkan kepada anak, maka seringkali sekolah menjadi tempat dimana budaya kekerasan berbasis gender dikekalkan. Pada saat yang sama, pengabaian isu gender di PAUD juga bisa juga mempertahankan budaya diskriminasi gender (gender discrimination) dimana baik perempuan maupun laki-laki terhalang aksesnya terhadap berbagai bidang kegiatan seperti dalam permainan outdoor salah satunya.

\section{METODOLOGI PENELITIAN}

Penelitian ini berpegang pada pendekatan feminis poststrukturalis, yang mendekonstruksi makna dari sebuah objektivitas dan mengedepankan gagasan subjektifitas. Karena dalam teori poststrukturalis feminis, tidak ada kebenaran obyektif yang dapat di akui secara umum dan luas, setiap kebenaran selalu dibangun berdasarkan kondisinya.

Makalah ini bertujuan untuk mengeksplorasi bagaimana gender dikonstruksi melalui kegiatan permainan luar ruangan di setting PAUD. Ini didasarkan pada studi etnografi selama enam bulan di sebuah taman kanak-kanak di Palembang, Indonesia. Etnografi digunakan dalam penelitian ini karena memungkinkan saya untuk memiliki pemahaman yang lebih dalam tentang praktik sehari-hari anak di taman kanak-kanak. Pengamatan dicatat dalam bentuk catatan lapangan. Saya juga melakukan wawancara informal dengan dua orang guru dan orang tua anak-anak, serta melakukan percakapan sehari-hari dengan 15 anak, yang berusia antara dua sampai enam tahun.

Terdapat 7 ruang kelas dengan jumlah siswa sekitar 100 anak yang ada di TK ini. Anak-anak tersebut sebagian besar berasal dari kelas menengah. Pembagian kelas di TK ini berdasarkan usia anak yang dikelompokkan menjadi empat tingkatan. Usia 2-3 tahun untuk kelas Joey 1, usia 3-4 tahun untuk kelas Joey 2, usia 4-5 tahun untuk kelas Kanga 1 dan usia 5-6 tahun untuk kelas Kanga 2. Guru di TK ini dipanggil dengan sapaan "Miss". Meskipun 
bukan sekolah internasional, namun TK ini memiliki kurikulum yang memodifikasi kurikulum nasional dengan kurikulum luar negeri. Sehingga bahasa yang digunakan di TK ini lebih banyak menggunakan bahasa Inggris.

Ruang bermain di TK ini lebih banyak di setting dengan konsep indoor. Kecuali kolam renang, lapangan depan, dan ruang perosotan yang berada di luar ruangan (outdoor). Permainan outdoor di TK Cerdas Kreatif ini dilakukan setiap hari selama 15-30 menit sebelum anak berbaris memasuki kelas. Dengan kata lain, permainan outdoor ini dilakukan ketika waktu permainan bebas yang dimainkan pagi hari ketika anak datang ke sekolah.

\section{HASIL DAN PEMBAHASAN}

Seperti yang disebutkan diatas, permainan outdoor ini dilakukan setiap hari. Anak anak melakukannya secara bebas. Dengan banyak pilihan permainan yang tersedia. Anak-anak tidak dibatasi dengan teman bermain berdasarkan kelas. Anak usia 4 tahun ikut bermain dengan anak 5 dan 6 tahun. Anak bebas memilih permainan yang akan ia mainkan dan di ruang bermain mana yang akan ia gunakan. Guru di TK Cerdas Kreatif ini berjaga di setiap ruang bermain berdasarkan jadwal piket jam bermain bebas, seperti misalnya di lapangan ada 2 guru yang berjaga di pinggir lapangan mengawasi aktivitas bermain anak. TK Cerdas Kreatif ini juga dilengkapi dengan kamera CCTV.

Ketika anak-anak sedang bermain di lapangan, ada anak yang terlibat dalam beberapa percakapan seperti yang saya dokumentasikan pada cuplikan berikut:

\section{Queeni: Nico, saya boleh ikut bermain ya}

Nico: Kamu kan perempuan, main nya sama anak perempuan di playroom aja, disini anak laki-laki sетиа.

Ada anggapan yang diyakini anak bahwa anak laki-laki bermain dengan anak laki-laki, dan anak perempuan bermain dengan temannya sesame perempuan. Terdapat pula relasi kuasa ketika anak sedang bermain di area outdoor, anak laki-laki karena merasa sedang bermain sepak bola bersama teman laki-lakinya, maka anak perempuan tidak boleh ikut serta didalamnya. Padahal baik anak-laki maupun anak perempuan dapat melangsungkan permainan secara bersamasama tanpa terbatas ruang bermain dan jenis permainan.

Temuan lainnya tentang bagaimana gender dalam permainan outdoor ini juga didapat dari hasil wawancara dengan guruguru di TK Cerdas Kreatif. Miss Lily yang saat itu sedang berjaga di area outdoor play menyarankan Queeni dan anak perempuan lainnya untuk bermain di playroom saja.

“iya Miss, lebih baik anak perempuan disatukan dengan anak perempuan, biar enak mengontrolnya, Miss”, Ungkap Miss Lily ketika saya bertanya kenapa ia juga meminta Queeni bermain di playroom saja. 30 
Dalam hal ini, artinya pengetahuan guru tentang ruang bermainan dan pilihan permainan yang berkeadilan gender belum terlihat. Guru masih menjadi tempat dimana bias gender dalam permainan di PAUD di kekalkan.

Mitos tentang anak laki-laki mendominasi area permainan outdoor dan anak perempuan di area permainan indoor, atau anak perempuan bermain dengan sesama anak perempuan dan anak laki-laki bermain dengan sesama anak laki-laki saja. Mitos ini dapat kita hilangkan dengan memberikan akses yang sama dan seluas-luasnya pada semua anak terlepas dari apa jenis kelamin mereka (Lestari \& Yulindrasari, 2020)

Seperti yang diungkapkan oleh beberapa penelitian sebelumnya bahwa salah satu hal yang membuat gender dianggap tidak penting di PAUD seringkali tergambar dalam konstruksi permainan di sekolah. Rangkaian penelitian yang dilakukan dari tahun 1970 sampai tahun 1980 menunjukkan bagaimana sekolah memperkuat ide bahwa terdapat perbedaan yang fundamental antara anak laki-laki dan perempuan bahkan untuk hal-hal yang sebetulnya tidak berbeda.

Ketidakadilan gender juga sudah dilahirkan dari sejak PAUD. Sebagai contoh, penelitian yang dilakukan oleh (Adriany \& Warin, 2014) menunjukkan bagaimana guru lebih sering meminta anak laki-laki menjadi pemimpin dibandingkan anak perempuan.
Penelitian lain yang dilakukan oleh (Keddie, 2003) menunjukkan bagaimana anak lakilaki lebih sering diberikan kesempatan bermain balok dibandingkan anak perempuan. Sementara itu penelitian yang dilakukan oleh Paechter (2007) juga menunjukkan bahwa anak laki-laki lebih mendominasi area terbuka dibandingkan dengan anak perempuan. Perbedaan perlakukan terhadap anak laki-laki dan perempuan ini nampaknya akan terus berlanjut pada banyak aktivitas.

Di Indonesia sampai hari ini misalnya kita menyaksikan bahwa angka partisipasi laki-laki di berbagai cabang olahraga outdoor juga masih lebih tinggi dibandingkan dengan tingkat partisipasi perempuan. Padahal upaya dalam meraih kesetaraan gender sebenarnya telah dirintis sejak lama. Program SDGs memaparkan kesetaraan gender atau gender equality menjadi salah satu tujuan dari pembangunan yang berkelanjutan. Sebagaiamana negaranegara lain di dunia, maka pemerintah Indonesia pun berusaha untuk mengimplementasikan pengarusutamaan gender (gender mainstreaming) dalam seluruh bidang kehidupan termasuk di bidang pendidikan dan semua akses di dalamnya. Hal ini dilakukan guna menghapuskan berbagai macam diskriminasi yang akan mempercepat terwujudnya kesetaraan gender (Kementerian 
Pemberdayaan Perempuan dan Perlindungan Anak, 2018).

Anak memiliki energy untuk kemudian ia salurkan dalam banyak kegiatan, kegiatan fisik pada lingkungan luar ruangan yang alami menjadi salah satu pilihannya. Lingkungan dalam hal ini mencakup akses ruang dan akses kesamaan hak dalam penggunaan tempat yang memiliki pengaruh terbesar pada durasi dan intensitas permainan anak yang aktif secara fisik. Kebutuhan akan permainan luar ruangan di taman kanak-kanak harus diberikan perhatian yang lebih besar (Dealey \& Stone, 2018)

Urgensi bermain dan bergerak sangat penting bagi kehidupan anak-anak yang berdampak pada pengembangan keterampilan kognitif, fisik, dan sosial. Kinerja fisik bermain di ruang bermain di luar ruangan anak-anak TK memungkinkan lingkungan bermain yang merangsang untuk anak-anak (Azlina \& S., 2012). Seperti yang dilansir Bjørgen (2016) ketika anak-anak tidak di luar, mereka gagal belajar tentang di luar ruangan. Jika anak-anak tidak dapat secara fisik mengeksplorasi, dengan kecepatan mereka sendiri, bagaimana mereka dapat memahami topografi lingkungannya. Aktivitas fisik, melalui permainan di luar ruangan juga dipercaya sebagai cara untuk meningkatkan kesehatan anak-anak dengan cara membina perkembangan mental dan sosial serta fisiologis yang sehat. Namun, di banyak negara salah satunya Indonesia, kesempatan bermain otonom anak-anak telah berkurang karena intensifikasi perkotaan dan menurunnya izin orang tua.

\section{KESIMPULAN DAN SARAN}

Kesempatan bermain luar ruangan ini juga hendaknya terbuka untuk semua gender. Melalui dekonstruksi mitos yang selama ini dilanggengkan bahwa yang bermain sepak bola itu anak laki-laki saja. Atau ketika anak perempuan sedang bermain lompat tali dan pada tempat dan waktu yang bersamaan anak laki-laki juga sedang bermain bola atau larilarian ala superhero, selalu anak perempuan yang harus mengalah. Asumsi bahwa kelembutan, kasih sayang, rasa ingin berbagi termasuk ketika bermain diidentikkan dengan anak perempuan merupakan sesuatu yang sebenarnya dapat dipertukarkan. Bermain luar ruangan seperti bola atau bermain peran superhero juga bisa dalam kelompok yang mencampur laki-laki dan perempuan sehingga kolaborasi dalam sosialisasi anak dapat lebih terasa. Sehingga Dengan demikian, tidak ada lagi relasi kuasa yang lebih dominant dan pihak lain yang termarginalkan dalam konteks permainan di anak usia dini.

Oleh karena itu, Pendidikan anak usia dini (PAUD) harus memiliki wawasan gender yang dipahami berdasarkan 
pemahaman bermain anak untuk mengatasi penindasan berbasis gender dalam konteks sekolah. Dimana kondisi social lingkungan berkaitan dengan permainan outdoor dari berbagai usia dan gender, yang kemudian diimplementasikan menjadi tindakan dalam beberapa kebijakan. Kebijakan ini bertujuan meningkatkan karakteristik lingkungan fisik yang erat kaitannya dengan permainan outdoor yang harus mempertimbangkan usia dan sensitif serta responsif gender.

\section{DAFTAR PUSTAKA}

Adriany, V. (2019a). Being a princess: young children's negotiation of femininities in a Kindergarten classroom in Indonesia. Gender and Education, 31(6), 724-741. https://doi.org/10.1080/09540253.2018. 1496229

Adriany, V. (2019b). 'I don't want to play with the Barbie boy': Understanding Gender-Based Bullying in a Kindergarten in Indonesia. International Journal of Bullying Prevention, 1(4), 246-254. https://doi.org/10.1007/s42380-01900046-2

Adriany, V., \& Warin, J. (2014). Preschool teachers' approaches to care and gender differences within a child-centred pedagogy: findings from an Indonesian kindergarten. International Journal of Early Years Education, 22(3), 315-328. https://doi.org/10.1080/09669760.2014. 951601

Azlina, W., \& S., Z. A. (2012). A Pilot Study: The Impact of Outdoor Play Spaces on Kindergarten Children. Procedia - Social and Behavioral Sciences. https://doi.org/10.1016/j.sbspro.2012.03 .349
Bjørgen, K. (2016). Physical activity in light of affordances in outdoor environments: qualitative observation studies of 3-5 years olds in kindergarten. SpringerPlus. https://doi.org/10.1186/s40064-0162565-y

Dealey, R. P., \& Stone, M. H. (2018). Exploring Out-of-School Play and Educational Readiness. Early Childhood Education Journal, 46(2), 201-208. https://doi.org/10.1007/s10643-0170849-7

Dinella, L. M., \& Weisgram, E. S. (2018). Gender-Typing of Children' $s$ Toys : Causes, Consequences, and Correlates Why Are There Gender Differences in Toy. Sex Roles, 79(5-6), 253-259.

DiPrete, T. A., \& Jennings, J. L. (2012). Social and behavioral skills and the gender gap in early educational achievement. Social Science Research. https://doi.org/10.1016/j.ssresearch.201 1.09.001

Fakih, M. (2013). Analisis Gender dan Transformasi Sosial. Yogyakarta: Pustaka Pelajar

Keddie, A. (2003). Little Boys: Tomorrow's macho lads. Discourse. https://doi.org/10.1080/0159630032000 172498

Kementerian Pemberdayaan Perempuan dan Perlindungan Anak. (2018). Pembangunan manusia berbasis gender. In Kementerian Pemberdayaan Perempuan dan Perlindungan Anak (Vol. 95).

Kollmayer, M., Schober, B., \& Spiel, C. (2018). Gender stereotypes in education: Development, consequences, and interventions. European Journal of Developmental Psychology, 15(4). 
https://doi.org/10.1080/17405629.2016. 1193483

Lynch, M. (2015). Guys and dolls: a qualitative study of teachers' views of gendered play in kindergarten. Early Child Development and Care, 185(5), 679-693.

https://doi.org/10.1080/03004430.2014. 950260

Lestari, M., \& Yulindrasari, H (2020, August). Gender and Reading Literacy in Early Childhood Education. In
International conference on Early Childhood Education and Parenting 2019 (ECEP 2019) (pp. 174-176) Atlantis Press.

MacNaughton, G. (2000). Rethinking Gender in Early Childhood Education. New South Wales: Allen \& Uwin

Mac Naughton, G. (2005). Doing Foucault in Early Childhood Studies Contesting Early Childhood Series Series Editors: Gunilla Dahlberg and Peter Moss. 